PEMBELAJAR: Jurnal Ilmu Pendidikan, Keguruan, dan Pembelajaran

Volume 1 Nomor 2 Oktober 2017

e-ISSN: 2549-9114 dan p-ISSN: 2549-9203

(Received: Agustus-2017; Reviewed: September-2017; Published: Oktober 2017)

\title{
Kompetensi Widyaiswara Dan Kualitas Diklat
}

\author{
Hamzah \\ Widyaiswara Balai Diklat Keagamaan Makassar \\ Corresponding e-mail: budiman_tahir@yahoo.co.id
}

\begin{abstract}
Abstrak: Tujuan artikel pemikiran ini adalah menekankan kembali peran widyaiswara dalam menentukan kualitas sebuah kegiatan pendidikan dan pelatihan. Beberapa hasil penelitian sebelumnya dikaji, dibandingkan dan disimpulkan guna melahirkan sebuah hasil pemikiran yang sekaligus dapat direkomendasikan untuk peningkatan dan perbaikan kegiatan Pendidikan dan pelatihan yang dapat diukur melalui tingkat kepuasan dan tingkat kepentingan peserta diklat terhadap kompetensi widyaiswara yang terdiri dari Kompetensi Pengelolaan Pembelajaran, Kompetensi Kepribadian, dan Kompetensi Substantif. Kesimpulan pada artikle ini :1) Widyaiswara harus mencermati ketiga kompetensi widyaiswara yang meliputi Kompetensi Pengelolaan Pembelajaran, Kompetensi Kepribadian, dan Kompetensi Substantif. 2) Kompetensi Pengelolaan Pembelajaran, perlu mendapat perhatian utama sesuai hasil penelitian sebelumnya, untuk dicarikan pemecahannya agar pada diklat berikutnya dapat memuaskan peserta diklat. 3) Kurikulum perubahan diklat kepemimpinan memiliki pengaruh positif dan signifikan terhadap kepuasan peserta diklat. Artinya Jika kurikulum perubahan sesuai dengan kebutuhan peserta dikat maka kepuasan peserta diklat akan semakin tinggi, sebaliknya semakin kurang baik dan kurikulum perubahan tidak sesuai dengan kebutuhan peserta diklat maka kepuasan peserta diklat akan semakin rendah.
\end{abstract}

Kata Kunci: kompetensi widyaiswara, kepuasan peserta diklat, kualitas diklat.

(i) (\$) (C) 2017 -Pembelajar Universitas Negeri Makassar.Ini adalah artikel dengan akses terbuka di bawah licenci CC BY-NC-4.0 (https://creativecommons.org/licenses/by-nc/4.0/)

\section{PENDAHULUAN}

Widyaiswara adalah figur sumber daya manusia yang memegang peran penting dalam pendidikan dan pelatihan (diklat). Ketika kita mempersoalkan masalah diklat, maka sosok widyaiswara mesti dibahas dalam agenda pembicaraan, terutama yang menyangkut persoalan proses pembelajaran dalam suatu diklat. Pada Peraturan Menteri Pendayagunaan Aparatur Negara dan Reformasi birokrasi Republik Indonesia, Nomor 22 Tahun 2014 tentang jabatan fungsional widyaiswara dan angka kreditnya, dituliskan bahwa:

Widyaiswara adalah PNS yang diangkat sebagai pejabat fungsional dengan tugas, tanggung jawab, wewenang, dan hak untuk melakukan kegiatan Dikjartih PNS, evaluasi dan Pengembangan Diklat pada Lembaga Pemerintah.
Widyaiswara merupakan tenaga fungsional yang profesional, bertugas mendidik, mengajar, dan melatih (dikjartih); diidealkan dengan konsep merencanakan dan melaksanakan proses pembelajaran, menilai proses dan hasil pembelajaran, melakukan pembimbingan, serta melakukan penelitian. Dijelaskan juga pada Peraturan Menteri Pendayagunaan Aparatur Negara dan Reformasi birokrasi Republik Indonesia, Nomor 22 Tahun 2014 tentang jabatan fungsional widyaiswara dan angka kreditnya, tugas pokok widyaiswara adalah melaksanakan dikjartih PNS, evaluasi dan pengembangan diklat pada Lembaga Diklat Pemerintah

Widyaiswara merupakan faktor utama dan penting dalam suatu diklat. Peserta sering menjadikan mereka sebagai tokoh teladan bahkan tokoh identifikasi diri. Pada suatu kegiatan diklat, widyaiswara merupakan unsur yang sangat mempengaruhi tercapainya tujuan 
diklat, selain unsur peserta dan fasilitas lainnya. Keberhasilan penyelenggaraan diklat sangat ditentukan oleh kesiapan widyaiswara dalam menyusun bahan ajar, rancang bangung pembelajaran mata diklat, rencana pembelajaran, dan ba han tayang pembelajaran. Sehubungan dengan itu, posisi strategis untuk meningkatkan mutu hasil diklat sangat dipengaruhi oleh kemampuan profesional widyaiswara dan mutu kinerjanya.

Widyaiswara dapat didentikkan sebagai ujung tombak dari diklat yang dilaksanakan, sebab secara langsung berupaya memfasilitasi, membangun, memberdayakan, dan mempengaruhi peserta diklat. Mereka memiliki kemampuan dasar yang diperlukan sebagai fasilitator, pendidik, pembimbing dan pengajar. Kemampuan tersebut merupakan cermin dari kompetensi yang dimilikinya. Oleh karena itu, berkualitas tidaknya proses diklat sangat tergantung pada kreativitas dan inovasi pembelajaran yang diterapkan oleh widyaiswara dalam pembelajarannya. Hal ini senada yang diungkapkan oleh Gunawan (1996) yang mengemukakan bahwa pendidik merupakan perencana, pelaksana sekaligus sebagai evaluator pembelajaran di kelas, maka peserta didik merupakan subjek yang terlibat langsung dalam proses untuk mencapai tujuan pendidikan. Kompetensi widyaiswara adalah pemilikan pengetahuan, keterampilan, dan kemampuan yang dituntut oleh Jabatan Fungsional Widyaiswara yang meliputi kompetensi pengelolaan pembelajaran, substansi, kepribadia, dan sosial

Kehadiran widyaiswara dalam proses pembelajaran dalam suatu diklat masih tetap memegang peranan yang penting. Peran tersebut belum dapat diganti dan diambil alih oleh apapun. Hal ini disebabkan karena masih banyak unsur-unsur manusiawi yang tidak dapat diganti oleh unsur lain.

\section{HASIL DAN PEMBAHASAN}

Peraturan Kepala Lembaga Administrasi Negara Nomor 5 Tahun 2008 tentang Instrumen Standar Kompetensi Widyaiswara menyebutkan bahwa Widyaiswara memiliki empat kompetensi, yaitu: pengelolaan pembelajaran, kepribadian, sosial, dan substantif. Keempat kompetensi tersebut didukung oleh masingmasing subkompetensi yang tentunya diharapkan untuk mencapai kompetensi dimaksud.

Dukungan subkompetensi untuk kompetensi pengelolaan pembelajaran adalah: (1) Membuat garis-garis besar program pembelajaran (GBPP)/Rancang bangun pembelajaran mata diklat (RBPMD) dan satuan acara pembelajaran (SAP)/rencana pembelajaran (RP); (2) Menyusun bahan ajar; (3) Menerapkan pembelajaran orang dewasa; (4) Melakukan komunikasi yang efektif dengan peserta; dan (5) Mengevaluasi pembelajaran. Sedangkan, dukungan subkompetensi untuk kompetensi kepribadian adalah: (1) Menampilkan pribadi yang diteladani; dan (2) Melaksanakan kode etik dan menunjukkan etos kerja sebagai widyaiswara yang profesional.

Dukungan subkompetensi untuk kompetensi sosial adalah: (1) Membina hubungan dan kerjasama dengan sesama widyaiswara; dan (2) Menjalin hubungan dengan penyelenggara/ pengelola lembaga diklat. Selanjutnya, dukungan subkompetensi untuk kompetensi substantif adalah: (1) Menguasai keilmuan dan keterampilan mempraktekkan sesuai dengan materi Diklat yang diajarkan; dan (2) Menulis karya tulis ilmiah yang terkait dengan lingkup kediklatan dan/atau pengembangan spesialisasinya.

Kompetensi widyaiswara yang hebat didukung oleh subkompetensi yang hebat. Selanjutnya, subkompetensi widyaiswara yang hebat tentunya didukung pula indikator pencapaian subkompetensi yang hebat pula. Indikator pencapaian subkompetensi dapat dirumuskan oleh widyaiswara sebagai bentuk kreativitas dan kemampuan berpikir.

Indikator pencapaian subkompetensi
membuat garis-garis besar program
pembelajaran (GBP)/rancang bangun
pembelajaran mata diklat (RBPMD) dan satuan
acara pembelajaran (SAP)/rencana pembelajaran
(RP) dirumuskan bahwa widyaiswara memiliki
kemampuan: (1) menyusun deskripsi singkat,
$\begin{array}{lll}\text { (2) menentukan tujuan mata diklat yang } \\ \text { diajarkan, (3) menentukan kegiatan }\end{array}$ pembelajaran yang sesuai dengan tujuan mata diklat yang diajarkan, (4) menentukan pokok bahasan dan subpokok bahasan, (5) menentukan alokasi waktu untuk setiap kegiatan belajar, (6) menentukan metode pembelajaran yang sesuai dengan tujuan pembelajaran, (7) menentukan 
alat bantu pembelajaran sesuai dengan materi dan tujuan pembelajaran, (8) menentukan referensi, dan (8) menentukan sistem evaluasi.

Indikator pencapaian subkompetensi membuat garis-garis besar program pembelajaran (GBPP)/rancang bangun pembelajaran mata diklat (RBPMD) dan satuan acara pembelajaran (SAP)/rencana pembelajaran (RP) di atas sejalan dengan pernyataan yang dikemukakan oleh Sanjaya (2009:28) :

"Dalam GBPP yang berbentuk matriks telah ditentukan dari mulai tujuan yang harus dicapai, materi pelajaran yang harus disampaikan, cara yang harus dilakukan termasuk penggunaan media dan sumber belajar serta bentuk evaluasi yang harus dilakukan sampai kepada penentuan waktu kapan materi pelajaran harus disampaikan."

Selanjutnya, indikator pencapaian subkompetensi menyusun bahan ajar dirumuskan bahwa widyaiswara memiliki kemampuan: (1) menentukan bahan ajar secara sistimatis, (2) menyusun materi yang sesuai dengan tujuan pembelajaran, dan (3) menentukan referensi yang sesuai dengan materi pembelajaran.

Untuk melaksanakan pembelajaran orang dewasa, maka konsep belajar tuntas harus dimiliki. Bentuk dan karakteristik belajar tuntas dapat diketahui dari beberapa ciri sebagai berikut: setiap tujuan pembelajaran dinyatakan secara jelas dan terukur dan memuat apa yang seharusnya dilakukan oleh peserta; tujuan-tujuan pembelajaran harus dikelompokkan; tujuan pembelajaran harus merupakan pilihan tindakan yang benar-benar dan mungkin dapat dilakukan; dan tujuan pembelajaran harus menggambarkan urutan (Aunurrahman, 2010:168-169).

Berdasarkan konsep belajar tuntas tersebut, maka untuk indikator pencapaian subkompetensi menerapkan pembelajaran orang dewasa dirumuskan bahwa widyaiswara memiliki kemampuan: (1) menjelaskan tujuan pembelajaran secara umum dan khusus, (2) menyampaikan materi pembelajaran secara sistimatis sesuai dengan rencana pembelajaran, (3) melibatkan partisipasi peserta dalam proses pembelajaran, dan (4) mengelola kelas.

Sedangkan indikator poin 3 di atas "melibatkan partisipasi peserta dalam proses pembelajaran" selaras dengan tujuan pembelajaran orang dewasa yang dikemukakan oleh Hamzah (2007:61), yaitu "Membangkitkan semangat percaya diri dan optimisme; memberikan kemampuan dan keterampilan untuk berbuat sesuatu; dan memberi kemampuan untuk dapat menerima atau menolak sesuatu atas dasar standar peraturan, nilai-nilai, atau etika masyarakat yang dianutnya.

Terkait dengan peserta diklat, maka untuk indikator pencapaian subkompetensi melakukan komunikasi yang efektif dengan peserta dirumuskan bahwa widyaiswara memiliki kemampuan: (1) menguasai teknikteknik komunikasi secara efektif, dan (2) menggunakan alat bantu secara terampil sesuai dengan situasi pembelajaran. Selanjutya, masih terkait dengan peserta diklat, bahwa untuk indikator pencapaian subkompetensi memotivasi semangat belajar peserta dirumuskan bahwa widyaiswara memiliki kemampuan: mengetahui keinginan peserta terhadap materi pembelajaran, (2) menerapkan metode/teknik pembelajaran yang sesuai dengan karakteristik peserta diklat dan materi pembelajaran, dan (3) mendorong peserta untuk memberikan komentar/argumentasi. Sedangkan, untuk indikator pencapaian subkompetensi mengevaluasi pembelajaran dirumuskan bahwa widyaiswara memiliki kemampuan menilai daya serap peserta terhadap materi pembelajaran.

Self mastery (penguasaan diri) widyaiswara yang terdiri atas: wawasan kebangsaan, integritas, dan etika, merupakan jaminan dalam pelaksanaan tugasnya untuk mendidik, mengajar, dan melatih (dikjartih), karena terkait langsung dengan kompetensi kepribadian dari widyaiswara itu sendiri. Untuk indikator pencapaian subkompetensi menampilkan pribadi yang diteladani dirumuskan bahwa widyaiswara memiliki kemampuan: (1) memperlakukan peserta diklat tanpa membedakan agama, adat istiadat daerah asal, suku, dan gender; (2) berprilaku jujur, adil, tegas, dan konsisten; dan (3) mengendalikan diri dalam berinteraksi. Sedangkan, untuk indikator pencapaian subkompetensi melaksanakan kode etik dan menunjukkan etos kerja sebagai widyaiswara yang profesional dirumuskan bahwa mereka memiliki kemampuan: (1) Menunjukkan penampilan diri yang santun, (2) Menunjukan sikap dan perilaku tanpa pamrih, (3) Bekerja secara mandiri, (4) Menunjukkan kedisiplinan, (5) Menunjukan kreativitas, (6) Menunjukkan tingkah laku yang bertanggung jawab, (7) Bekerja secara tim, (8) Menunjukkan 
loyalitas, dan (9) Mengembangkan diri sesuai dengan tuntutan kemajuan lingkungan.

Indikator pencapaian subkompetensi membina hubungan dan kerjasama dengan sesama widyaiswara dirumuskan bahwa widyaiswara memiliki kemampuan: (1) Berkomunikasi secara baik dengan sesama widyaiswara, (2) Bekerjasama dengan sesama widyaiswara, (3) Bertindak dan berprilaku yang menimbulkan rasa empati dan simpati kepada sesama widyaiswara, dan (4) Bertindak sesuai norma-norma keagamaan dan masyarakat. Sedangkan, untuk indikator pencapaian subkompetensi menjalin hubungan dengan penyelenggara/pengelola lembaga diklat dirumuskan bahwa widyaiswara memiliki kemampuan: (1) Berkomunikasi secara baik dengan penyelenggara/ pengelola diklat, (2) Menghormati penyelenggara/pengelola diklat, dan (3) Berperilaku dan bertindak yang menimbulkan rasa simpati dan empati pada penyelenggara/ pengelola diklat.

Kompetensi substantif harus dimiliki oleh widyaiswara. Untuk indikator pencapaian subkompetensi menguasai keilmuan dan keterampilan mempraktekkan sesuai dengan materi diklat yang diajarkan dirumuskan bahwa widyaiswara memiliki kemampuan: menjelaskan substansi materi yang diajarkan, (2) mengaplikasikan substansi materi yang diajarkan, (3) merespon tanggapan/pertanyaan peserta, dan (4) menganalisis substansi materi yang diajarkan. Sedangkan, untuk indikator pencapaian subkompetensi menulis karya tulis ilmiah yang terkait dirumuskan bahwa widyaiswara memiliki kemampuan: (1) menguasai sistimatika penulisan, (2) menguasai metodologi penelitian, (3) menguasai teknik penulisan karya tulis ilmiah, dan (4) mengaalisis hasil penelitian.

\subsection{Diklat Berkualitas dengan Widyaiswara Bertanggung Jawab}

Secara filosofis, pendidikan dalam suatu diklat diartikan sebagai upaya membantu peserta diklat mengembangkan potensinya guna menghadapi kehidupan pasca diklat. Dengan demikian, diklat dikatakan bermutu, jika dapat melahirkan lulusan yang mampu menghadapi tantangan kehidupan yang dihadapinya.

Pembahasan makna diklat yang bermutu sangat penting, karena kata diklat dewasa ini sedang misleading, karena seakan semua peserta diklat harus lulus dan memuaskan. Semangat untuk menguasai materi pelajaran begitu kuat, sehingga semua energi difokuskan dan lupa bahwa penguasaan sesungguhnya barulah tahap awal, yang masih harus dilanjutkan dengan belajar menggunakannya untuk memecahkan problema kehidupan.

Dalam konteks ini, kehidupan haruslah dimaknai secara luas dan bukan kehidupan para lulusan diklat. Dengan demikian, mata diklat haruslah dipahami sebagai alat, sedangkan tujuannya adalah menghadapi dan memecahkan problem kehidupan. Peserta mengikuti proses pembelajaran dalam diklat agar dapat lebih mudah memahamai fenomena kehidupan serta memecahkan problema yang terjadi.

Jika makna pendidikan bermutu seperti yang diuraikan di atas digunakan sebagai paradigma pendidikan bermutu, maka widyaiswara harus mampu dan selalu berusaha mengaitkan materi ajar dengan kehidupan peserta diklat dan memfasilitasi dan membimbing peserta diklat untuk belajar memecahkan problema kehidupan dengan memanfaatkan ilmu yang dipelajari.

Dengan demikian kemampuan widyaiswara dalam mengaitkan mata diklat yang diajarkan dengan kehidupan sehari-hari menjadi syarat sangat penting dan lebih dari itu, kemampuan untuk bersusah payah memfasilitasi peserta diklat lebih penting lagi. Pola pembelajaran seperti itulah yang kini disebut dengan pembelajaran kontekstual dan problem based learning. Sementara itu, pola pembelajaran induktif haruslah dikuasai widyaiswara, sehingga dapat memulai pembelajaran dengan mengajak peserta diklat mendiskusikan fenomena keseharian, kemudian baru dikaitkan konsep/topik/kompetensi yang akan dipelajari.

Seiring dengan pola di atas, harus dipahami bahwa dalam pembelajaran yang menjadi titik fokus adalah apa yang dilakukan peserta diklat dan bukan apa yang dilakukan oleh widyaiswara. Yang menjadi titik fokus adalah pengalaman belajar yang diperoleh peserta diklat dan bukan pengalaman mengajar yang diperoleh widyaiswara. Widyaiswara perlu menyadari, bahwa dengan prinsip pembelajaran yang mendidik, yang akan ditanyakan sebagai prestasi widyaiswara bukan widyaiswara sudah mengajarkan apa, tetapi "peserta diklat sudah mengerjakan apa", "peserta diklat memperoleh pengalaman belajar 
apa", dan "peserta diklat sudah menguasai kompetensi apa". Apa yang dilakukan widyaiswara hanyalah sebatas penyediaan wahana atau fasilitas, tetapi yang diukur sebagai prestasi adalah apa yang dikerjakan peserta diklat dan kompetensi yang telah dikuasai setelah mengalami kegiatan tersebut.

Pergeseran paradigma berpikir seperti itulah yang kini disebut pegeseran pembelajaran, dari teaching ke learning. Artinya dalam pendidikan, yang penting apa yang dicapai (dipelajari/dikuasai) oleh peserta diklat dan bukan apa yang dilakukan (diajarkan) oleh widyaiswara. Untuk mampu melaksanakan pola ini, widyaiswara dituntut mampu mendeteksi apakah peserta diklat sudah memahami konsep yang dipelajari atau belum, apakah peserta diklat sudah memperoleh pengalaman belajar yang diperlukan atau belum dan lebih dari itu widyaiswara harus peka terhadap kesulitan belajar yang dialami oleh peserta diklat. Kepekaan itu penting, karena banyak widyaiswara yang mampu mengerjakan tetapi tidak peka dan tidak berempati terhadap kesulitan peserta diklat, sehingga tidak terdorong untuk membantunya.

Kepekaan widyaiswara terhadap problem peserta diklat itu ternyata bukan semata-mata terkait dengan hal-hal yang bersifat kognitif/pengetahuan, tetapi justru lebih banyak terkait dengan sikap dan kesadaran diri. Diperlukan kesadaran akan tugas widyaiswara adalah membantu peserta diklat untuk mencapai penguasaan kompetensi tertentu. Diperlukan rasa empati kepada peserta diklat yang menghadapi kesulitan dan bukan menyalahkan peserta diklat, dengan argumentasi peserta diklat malas atau kemampuan dasarnya lemah. Diperlukan kesadaran bahwa itulah tugas widyaiswara untuk membuat peserta diklat yang malas menjadi rajin dan peserta diklat yang kemampuan dasarnya rendah tetap mencapai kompetensi sesuai dengan potensi optimalnya.

Jika dikaitkan dengan kompetensi widyaiswara, di sinilah pentingnya kompetensi kepribadian secara implementatif. Kepribadian yang mantap, stabil, arif dan berujung sebagai teladan harus terwujud bahwa widyaiswara menjadi sosok yang dipercaya dan diteladani oleh peserta diklat (dalam kelakar bahasa Jawa "digugu lan ditiru").

Walaupun tampaknya sederhana, pengalaman menunjukkan implementasi pendidikan bermakna (meaningful learning) yang diarahkan pada penguasaan kecakapan hidup dan penggeseran paradigma pembelajaran dari teaching ke learning, ternyata tidak mudah. Diperlukan perubahan pola pikir dan bukan sekedar peningkatan kemampuan/keterampilan. Widyaiswara yang sudah terbiasa mengajar dengan orientasi materi ajar cukup sulit yang bergeser ke orientasi kecakapan hidup. Demikian pula widyaiswara yang terbiasa berparadigma teaching ternyata sulit bergeser ke paradigma learning.

Dengan ikatan dan tanggung jawab untuk mencapai target yang telah ditetapkan, diharapkan widyaiswara dan semua warga sekolah terdorong untuk selalu melakukan inovasi guna peningkatan mutu. Peningkatan mutu hanya dapat terjadi secara berkelanjutan, jika dilakukan inovasi yang berkelanjutan pula. Inovasi sebaiknya tidak hanya mencakup bagaimana mencapainya (strategi/program), tetapi juga apa yang ingin dicapai (apa yang seharusnya dicapai oleh peserta diklat, sebagai bentuk mutu diklat).

\subsection{Penelitian Relevan Sebelumnya}

2.2.1. Teguh Nugraha, 2014. Penelitian ini berjudul "Pengaruh Kompetensi Pengelolaan Pembelajaran Widyaiswara Terhadap Mutu Layanan Pembelajaran di Pusdiklat Geologi”. Universitas Pendidikan Indonesia.

Masalah yang dikaji dalam penelitian ini adalah seberapa besar pengaruh kompetensi pengelolaan pembelajaran widyaiswara terhadap mutu layanan pembelajaran di lembaga diklat. Kesimpulan penelitian ini adalah adanya pengaruh yang positif dan signifikan antara kompetens pengelolaan pembelajaran widyaiswara terhadap mutu layanan pembelajaran di Pusdiklat Geologi. Adapun saran dari peneliti terkait mutu layanan pembelajaran adalah lembaga maupun widyaiswara harus terus meningkatkan kemampuan ataupun kompetensi widyaiswara dan lembaga harus meningkatkan kualitas layanan khususnya layanan pembelajaran.

2.2.2. Supono, 2015. Evaluasi Kepuasan Peserta Diklat Terhadap Kompetensi Widyaiswara Program Studi Plambing dan Sanitasi Departemen Bangunan P4TK Bidang Otomotif dan Elektronika Malang. Pusat Pengembangan Dan 
Pemberdayaan Pendidik Dan Tenaga Kependidikan Bidang Otomotif \& Elektronika Malang.

Penelitian ini

pada peserta diklat yang

dilakukan sedang mengikuti diklat di Program Studi Plambing dan Sanitasi

Departemen Bangunan PPPPTK BOE Malang pada bulan Mei 2012 sampai dengan bulan September 2012. Hasil penelitian menunjukkan bahwa rerata tingkat kepuasan peserta diklat terhadap kompetensi Widyaiswara sebesar 4,38 dan nilai ini termasuk kategori puas, sedangkan tingkat kepentingan peserta diklat sebesar 4,68dan nilai ini termasuk kategori sangat penting.

$$
\text { Hasil Importance }
$$

Analysis (IPA) menunjukkan

bahwa variabel Kompetensi Pengelolaan Pembelajaran tidak memuaskan peserta padahal peserta menganggap keberadaannya sangat penting. Variabel Kompetensi Kepribadian telah memuaskan peserta dan peserta juga menganggap keberadaannya sangat penting. Sedangkan variabel Kompetensi Substantif tidak memuaskan peserta tetapi peserta menganggap keberadaannya tidak penting.

\subsection{3. de-Miguel, Mario,ect., 2011. Assessment of The Satisfaction Of Participants in Training for Employment [Evaluación de la satisfacción de los participantes en la formación profesional para el empleo]. Universidad de Oviedo (España). http://www.uv.es/RELIEVE/v17n1/RELI EVEv17n1 3eng.htm}

Artikel ini merupakan rangkuman dari penelitian yang dikembangkan mengevaluasi Kepuasan Peserta dalam kegiatan pelatihan dipromosikan oleh Plan Training for Employment (FPE) dari Kerajaan Asturias selama periode tersebut antara tahun 2002 dan 2008. Untuk melaksanakan penelitian ini peneliti telah melakukan penelitian observasional berdasarkan survey. Hasil yang diperoleh secara keseluruhan menunjukkan tingkat tinggi kepuasan peserta dengan kegiatan pelatihan dipromosikan. Dengan rencana itu, meski perbedaan jelas terdeteksi sesuai dengan variabel klasifikasi yang digunakan dalam penelitian (jenis kelamin, usia, kelompok profesional, spesialisasi, dll).
Analisis informasi kualitatif dikumpulkan memungkinkan juga memiliki satu set komentar dan saran yang sangat berguna saat merumuskan proposal untuk meningkatkan pelatihan tindakan diimplementasikan Kesamaan yang tinggi antara data yang diperoleh dalam tujuh penilaian selama ini mendukung keabsahan temuan dan rekomendasi dalam setiap kasus, ditetapkan untuk perbaikan program pendidikan dievaluasi

\subsubsection{AEP KUSNAWAN. 2017 QUALITY} MANAGEMENT EDUCATION AND RELIGIOUS COUNSELOR TRAINING AEP KUSNAWAN Management of Dakwah, Dakwah and Comunication, Islamic States University of Sunan Gunung Djati Bandung, Bandung, Indonesia. International Journal of Human Resource Management and Research (IJHRMR) ISSN(P): 2249-6874; ISSN(E): 2249-7986 Vol. 7, Issue 1, Feb 2017, 49-56 @ TJPRC Pvt. Ltd.

Tujuan dari penelitian ini adalah untuk mengetahui: Bagaimana masukan manajemen kualitas pendidikan dan konselor agama pelatihan, proses manajemen mutu pendidikan dan pelatihan konselor, hasil manajemen mutu pelatihan pendidikan dan konseling agama, model konseptual pendidikan manajemen mutu dan pelatihan konselor agama di Pusat Pelatihan Agama Bandung.

Program Pendidikan dan Pelatihan (Bahasa Indonesia: Diklat) konselor agama di Pusat Pelatihan Bandung menunjukkan bahwa pelatihan manajemen mutu konselor berdasarkan nilai integritas, profesionalisme, keunggulan, transparansi, akuntabilitas, dan kebersamaan. Nilai tersebut dicapai melalui manajemen kualitas input proses, manajemen mutu dan hasil keluaran manajemen mutu.

\section{KESIMPULAN}

Berdasarkan hasil analisis dan pembahasan pada bab sebelumnya, maka dapat diambil kesimpulan sebagai berikut :

A. Semua pihak penyelenggara dikat, terutama Widyaiswara harus mencermati ketiga kompetensi widyaiswara yang meliputi Kompetensi Pengelolaan

Pembelajaran, Kompetensi Kepribadian, dan Kompetensi Substantif. 
B. Kompetensi Pengelolaan Pembelajaran, perlu mendapat perhatian utama sesuai hasil penelitian sebelumnya, untuk dicarikan pemecahannya agar pada diklat berikutnya dapat memuaskan peserta diklat.

C. Kurikulum perubahan diklat kepemimpinan memiliki pengaruh positif dan signifikan terhadap kepuasan peserta diklat di Badan Pendidikan dan Pelatihan. Artinya semakin baik dan kurikulum perubahan sesuai dengan kebutuhan peserta diklat maka kepuasan peserta diklat akan semakin tinggi, sebaliknya semakin kurang baik dan kurikulum perubahan tidak sesuai dengan kebutuhan peserta diklat maka kepuasan peserta diklat akan semakin rendah.

\section{DAFTAR PUSTAKA}

Aep Kusnawan. 2017 Quality Management Education And Religious Counselor TRAINING AEP KUSNAWAN Management of Dakwah, Dakwah and Comunication, Islamic States University of Sunan Gunung Djati Bandung, Bandung, Indonesia. International Journal of Human Resource Management and Research (IJHRMR) ISSN(P): 2249-6874; ISSN(E): 22497986 Vol. 7, Issue 1, Feb 2017, 49-56 () TJPRC Pvt. Ltd.

Aunurrahman. 2010. Belajar dan Pembelajaran. Bandung: Alfabeta.

de-Miguel, Mario,ect., 2011. Assessment Of The Satisfaction Of Participants in Training for Employment [Evaluación de la satisfacción de los participantes en la formación profesional para el empleo]. Universidad de Oviedo (España).

http://www.uv.es/RELIEVE/v17n1/REL IEVEv17n1_3eng.htm

Hamzah. 2007. Model Pembelajaran Menciptakan Proses Belajar Mengajar yang Kreatif dan Efektif. Jakarta: Bumi Aksara.

Harun, C.Z. 2000. . Pendidikan dan Pelatihan sebagai Sarana Pengembangan Sumber Daya Manusia di PT POS Indonesia (Persero), Analisis Sistem Penyelenggaraan Pendidikan dan Pelatihan di Pusdiklatpos Bandung, (Online), (http://digilib.upi.edu/pasca/available/et d-1202105-084810/, diakses 3 Nopember 2010)

Nasution, M.N. 2001. Manajemen Mutu Terpadu (Total Quality Management). Penerbit Ghalia Indonesia. Jakarta.

Nugraha Teguh, 2014. Penelitian ini berjudul "Pengaruh Kompetensi Pengelolaan Pembelajaran Widyaiswara Terhadap Mutu Layanan Pembelajaran di Pusdiklat Geologi". Universitas Pendidikan Indonesia.

Peraturan Kepala Lembaga Administrasi Negara Nomor 5 Tahun 2008 tentang Instrumen Standar Kompetensi Widyaiswara

Pranoto, J. 2003. Perspektif Jabatan Fungsional Widyaiswara dalam Pendidikan dan Pelatihan Pegawai Negeri Sipil, (Online),

(http://perpustakaan.upi.edu/abstrak/ad ministrasi/upload/juni_pranoto_perspekt if_jabatan_fungsional_Widyaiswara_dal am_pendidikan_dan_pelatihan_pegawai nnegeri_sipil.pdf, diakses 3 Nopember 2010)

Sanjaya. 2009. Kurikulum dan Pembelajaran.

Bandung: Kencana Prenada Media Grup.

Supono, 2015. Evaluasi Kepuasan Peserta Diklat Terhadap Kompetensi Widyaiswara Program Studi Plambing dan Sanitasi Departemen Bangunan P4TK Bidang Otomotif dan Elektronika Malang. Pusat Pengembangan Dan Pemberdayaan Pendidik Dan Tenaga Kependidikan Bidang Otomotif \& Elektronika Malang. Waspodo, M. 1999. Peranan Widyaiswara Dalam Implementasi Kurikulum Diklat SPAMA : Studi Deskriptif Analitik Pada Implementasi Kurikulum Diklat SPAMA Di Pusdiklat Pegawai Depdikbud, Sawangan, Jawa Barat, (Online), (http://digilib.upi.edu/p asca/available/etd-0922106-092226/, diakses 3 Nopember 2010

Peraturan Kepala Lembaga Administrasi Negara Nomor 5 Tahun 2008 Tentang Standar Kompetensi Widyaiswara

Peraturan Kepala Lembaga Administrasi Negara Nomor: 6 Tahun 2008 Tentang Pedoman Sertifikasi Widyaiswara 
Pembelajar: Jurnal Ilmu Pendidikan, Keguruan, dan Pembelajaran 1 (2) 2017

$\begin{array}{lll}\text { Peraturan } & \text { Menteri } & \text { Negara } \\ \text { Pendayagunaan Aparatur Negara } & \text { Negatan } \\ \text { Nomor: 14 Tahun 2009 tentang Jabatan } \\ \text { Fungsional Widyaiswara dan } & \text { Angka } \\ \text { Kreditnya } & \end{array}$

